\title{
Long non-coding RNAs in small cell lung cancer: A potential opening to combat the disease (Review)
}

\author{
TIAN-TIAN LI ${ }^{1}$, RONG-QUAN HE ${ }^{1}$, JIE MA $^{1}$, ZU-YUN LI ${ }^{2}$, XIAO-HUA HU ${ }^{1}$ and GANG CHEN ${ }^{2}$ \\ Departments of ${ }^{1}$ Medical Oncology and ${ }^{2}$ Pathology, The First Affiliated Hospital of \\ Guangxi Medical University, Nanning, Guangxi Zhuang Autonomous Region 530021, P.R. China
}

Received February 16, 2018; Accepted August 1, 2018

DOI: 10.3892/or.2018.6635

\begin{abstract}
Lung cancer is the top cause of cancer-associated mortality in men and women worldwide. Small cell lung cancer (SCLC) is a subtype that constitutes $\sim 15 \%$ of all lung cancer cases. Long non-coding RNAs (lncRNAs), possessing no or limited protein-coding ability, have gained extensive attention as a potentially promising avenue by which to investigate the biological regulation of human cancer. IncRNAs can modulate gene expression at the transcriptional, post-transcriptional and epigenetic levels. The current review highlights the developing clinical implications and functional roles of lncRNAs in SCLC, and provides directions for their future utilization in the diagnosis and treatment of SCLC.
\end{abstract}

\section{Contents}

1. Introduction

2. Molecular mechanisms of lncRNAs

Correspondence to: Professor Gang Chen, Department of Pathology, The First Affiliated Hospital of Guangxi Medical University, Nanning, Guangxi Zhuang Autonomous Region 530021, P.R. China E-mail: chen_gang_triones@163.com

Abbreviations: SCLC, small cell lung cancer; NSCLC, non-SCLC; EGFR, epidermal growth factor receptor; lncRNAs, long non-coding RNAs; snoRNAs, small nucleolar RNAs; snRNAs, small nuclear RNAs; ncRNAs, non-coding RNAs; miRNAs, microRNAs; HOTAIR, HOX transcript antisense intergenic RNA; HOX, homeobox; PRC2, polycomb repressive complex 2; TERC, telomerase RNA; TERT, telomerase reverse transcriptase; TFs, transcription factors; ceRNAs, competitive endogenous RNAs; HOTTIP, HOXA transcript at the distal tip; WDR5, WD repeat domain 5; EZH1, enhancer of zeste homolog 1; BCL-2, B-cell leukemia/lymphoma-2; CELF1, CUGBP Elav-like family member 1; EZH2, enhancer of zeste homolog 2; EMT, epithelial-to-mesenchymal transition; HOXA1, homeobox A1; TUG1, taurine upregulated gene 1; CCAT2, colon cancer-associated transcript 2; PVT1, plasmacytoma variant translocation 1; CCAT1, colon cancer associated transcript 1

Key words: long non-coding RNA, small cell lung cancer, molecular mechanism, biomarker, therapeutic target
3. Expression of lncRNAs in SCLC

4. Conclusions and future directions

\section{Introduction}

Lung cancer, recognized as the leading cause of cancerassociated mortality worldwide, is classified into small cell lung cancer (SCLC) and non-SCLC (NSCLC). SCLC constitutes $\sim 15 \%$ of all confirmed cases of lung cancer worldwide (1-3). Distinct from NSCLC, SCLC is unique in its inclination for quick metastasis and sensitivity to initial systemic cytotoxic chemotherapy. Systemic chemotherapy is the solid foundation of treatment for the limited and extensive stages of this disease. Nevertheless, the commonly adopted management standard of platinum-oriented chemotherapy has reached an efficacy bottleneck, mainly due to chemoresistance and relapse in SCLC patients (4). Despite plentiful clinical trials in the past four decades, systematic treatment for SCLC patients has not changed markedly. As a result, the majority of patients live for only 1 year or less following diagnosis, with the overall 5-year survival rate staying low at $<7 \%$ (5). The widely employed technique to diagnose SCLC from a tiny amount of malignant cells, in combination with a lack of proved predictive biomarkers that would require tissue biopsies and relatively rare surgical resection, has cut down the source of SCLC tissue for more profound studies (5). In NSCLC, a growing number of gene fusions or mutations instruct treatment selections for specific patient subgroups, particularly those with anaplastic lymphoma kinase or epidermal growth factor receptor (EGFR) (6) mutations. In marked contrast, numerous experimental and targeted agents regarding SCLC have failed to yield convincing clinical benefits (7). Novel and effective therapies for SCLC patients are urgently required. Regarding the molecular mechanisms of carcinogenesis, medical communities have mostly concentrated on genes with protein-coding capacity. Unexpectedly, the ENCODE project identified that up to three-quarters of the human genome could be transcribed, though $<3 \%$ of it encodes protein. This unexpected fact indicated that non-coding RNAs (ncRNAs) make up the vast majority of the human transcriptome (8). Long ncRNAs (lncRNAs) are >200 nucleotides in size and possess no or a very low protein-coding ability. Bioinformatics platforms and high-throughput sequencing emerging in recent 
years have facilitated uncovering the mystique of lncRNAs, which function as key molecules in wide-ranging cellular processes, including cell growth, adhesion, proliferation and apoptosis $(9,10)$. IncRNA deregulation is involved in numerous human diseases, and there is also increasing evidence suggesting that lncRNAs are involved in SCLC pathogenesis and clinical outcomes (11-15). Digging deeper into the biological functions and molecular mechanisms of lncRNAs will enable researchers to further understand the biology of SCLC and develop IncRNA-oriented therapeutics.

\section{Molecular mechanisms of IncRNAs}

What is lncRNA? The manifestation of lncRNAs owes much to the studies on the size, function and evolution of the human genome. Along with the development of DNA-RNA hybridization techniques, scientists have gradually become aware that the majority of the genome, which was initially labeled as 'junk DNA', does not encode proteins (16). However, subsequent studies demonstrating that small nucleolar RNAs (snoRNAs) and small nuclear RNAs (snRNAs) have a certain impact on post-transcriptional RNA processing propelled further investigation into non-coding sequences $(17,18)$. In the early 2000s, whole-transcriptome sequencing arose and carried forward the identification and annotation of numerous lncRNAs (19-21). ncRNAs can be large or small in size. Linearized ncRNAs with a length of $>200 \mathrm{bp}$ and with no or low protein-coding ability are known as lncRNAs. Small ncRNAs $(<200 \mathrm{bp})$ are categorized into PIWI-interacting RNAs, small interfering RNAs, microRNAs (miRNAs) and classical housekeeping ncRNAs, including transfer RNAs, ribosomal RNAs, snRNAs and snoRNAs. The FANTOM5 project has identified 19,175 potential functional lncRNAs in the human genome (22), yet few of them have been thoroughly investigated (23). Accumulating studies have supported the theory that at different levels, aberrant expression of IncRNAs serves crucial roles in cancer development, affecting cell growth, proliferation, apoptosis and metastasis via diverse mechanisms $(12,13,15,24)$.

Four archetypes of IncRNAs. IncRNAs are a set of ubiquitous genes participating in various biological mechanisms. There are four archetypes in which IncRNAs execute their molecular functions, namely as signals, decoys, guides and scaffolds (25). The signal archetype of IncRNAs may serve as markers of functionally significant biological events, as their expression exhibits cell type, time and space specificity. For example, lncRNA homeobox (HOX) transcript antisense intergenic RNA (HOTAIR) located in the HOXC locus exists in posterior and distal cells, whereas another HOXC lncRNA, Frigidair, is expressed in an anterior pattern. Conversely, lncRNA HOXA transcript at the distal tip (HOTTIP), located in the far end of the human HOXA cluster, is expressed in distal cells $(26,27)$. The decoys archetype is a type of IncRNA that regulates transcription through binding to and then carrying away protein targets, yet it does not exert extra functions. Decoys display as 'molecular sinks' for chromatin modifiers, transcription factors or other regulatory factors, all of which are RNA-binding proteins (25). For instance, by directly binding to and sequestering nuclear transcription factor Y subunit that drives a DNA damage-induced apoptotic program, lncRNA p21-associated ncRNA DNA damage-activated suppresses apoptotic gene expression to facilitate cell cycle arrest, leading to the promotion of cell survival (28). Knockdown of lncRNAs of this archetype may imitate the gain-of-function of the target proteins, while a rescue phenotype could be induced by loss-of-function of the IncRNA and its effector (25). The guides archetype of lncRNA can bind chromatin modifying proteins and direct the localization of ribonucleoprotein complexes to specific targets in a cis or trans manner. The well-known cis mechanism, mammalian $X$ inactivation center, specifies a set of ncRNAs, X-inactive specific transcript (Xist) included $(29,30)$. A 1.6-kb lncRNA, RepA RNA, stemming from the 5' end of Xist, produces polycomb repressive complex 2 (PRC2) in cis. $\mathrm{PRC} 2$ is involved in extra X-chromosome inactivation (31). In contrast to cis-regulatory lncRNAs, certain lncRNAs serve their chromosome-wide transcriptional roles in trans, such as IncRNA HOTAIR, which is capable of directing PRC2 to target genes in trans (32-34). The scaffolds archetype of IncRNA can act a platform where components are assembled, precisely regulating the sophisticated molecular interactions and signaling transductions involved in diverse biological signaling processes (35). For example, telomerase catalytic activity necessitates the combination of two common telomerase units, the telomerase RNA (TERC) and the telomerase reverse transcriptase (TERT). TERC is an essential lncRNA unit that offers the template for repeat synthesis, and it also possesses domains that promote TERT binding, catalytic activity and stability of the complex (36). Certain morbid states, including dyskeratosis congenital, presumably result from mutations altering the equilibrium between different conformations of TERC, more specifically, through destruction of the RNA scaffold structure where modular biding sites for telomeric regulatory proteins are located (37).

lncRNAs modulate gene expression at distinct levels. lncRNAs exert functions in an enormous range of biological processes by promoting or inhibiting the transcription and translation of protein-coding genes. Unlike highly conserved small ncRNAs that participate in gene silencing transcriptionally and post-transcriptionally (38-40), IncRNAs are poorly conserved and can modulate target gene expression via various mechanisms at different levels.

Transcriptional level. At the transcriptional level, lncRNAs have the following roles: i) Functioning as decoys for RNA polymerase II or transcription factors (TFs) to inhibit their binding to enhancers or promoters of target genes, therefore specifically promoting or repressing target gene expression (26); ii) alteration of TF localization or modification to promote or inhibit gene transcription (40); iii) interaction with DNA to form a triple helix structure, thereby affecting target gene transcription (41); and iv) presenting as competitive endogenous RNAs (ceRNAs) to inhibit the transcription of target genes (42).

Post-transcriptional level. At the post-transcriptional level, lncRNAs have the following roles: i) Providing different transcripts by regulating pre-mRNA alternative splicing (43); ii) combining with mRNAs to synthesize 
Table I. Information of five lncRNAs involved In SCLC.

\begin{tabular}{|c|c|c|c|c|c|c|}
\hline lncRNA & $\begin{array}{l}\text { Genomic } \\
\text { location }\end{array}$ & Dysregulation & Functions & Mechanism & $\begin{array}{c}\text { Publication } \\
\text { year }\end{array}$ & (Refs.) \\
\hline HOTTIP & $7 p 15.2$ & Upregulation & $\begin{array}{l}\text { Chemoresistance, shorter } \\
\text { survival, clinical stage }\end{array}$ & $\begin{array}{l}\mathrm{HOTTIP} / \mathrm{miR}-574-5 \mathrm{p} / \mathrm{EZH} 1 \\
\text { axis, HOTTIP/miR-216a/ } \\
\text { BCL-2 axis }\end{array}$ & 2017,2018 & $(57,58)$ \\
\hline HOTAIR & $12 q 13.13$ & Upregulation & $\begin{array}{l}\text { Lymphatic invasion, } \\
\text { chemoresistance }\end{array}$ & $\begin{array}{l}\text { Regulation of HOXA1 } \\
\text { methylation and target genes }\end{array}$ & 2013,2016 & $(66,67)$ \\
\hline TUG1 & $22 q 12.2$ & Upregulation & $\begin{array}{l}\text { Chemoresistance, clinical } \\
\text { stage and shorter survival }\end{array}$ & $\begin{array}{l}\text { Regulation of LIMK } 2 b \text { via } \\
\text { binding with EZH } 2\end{array}$ & 2017 & (76) \\
\hline CCAT2 & $8 q 24.21$ & Upregulation & $\begin{array}{l}\text { Malignant status, poor } \\
\text { prognosis }\end{array}$ & Unknown & 2016 & $(85)$ \\
\hline PVT1 & $8 \mathrm{q} 24.21$ & Upregulation & $\begin{array}{l}\text { Lymph node metastasis, } \\
\text { distal metastasis, and } \\
\text { clinical stage }\end{array}$ & Unknown & 2016 & (95) \\
\hline
\end{tabular}

SCLC, small cell lung cancer; HOTTIP, HOXA transcript at the distal tip; EZH1, enhancer of zeste homolog 1; BCL-2, B-cell leukemia/lymphoma-2; HOTAIR, HOX transcript antisense intergenic RNA; TUG1, taurine upregulated gene 1; CCAT2, colon cancer-associated transcript 2; PVT1, plasmacytoma variant translocation 1; HOXA1, homeobox A1; LIMK2b, LIM domain kinase 2; EZH2, enhancer of zeste homolog 2; miR, microRNA; lncRNA, long non-coding RNA.

double-stranded RNA complexes, thereby effectively enhancing the stability of mRNAs (44); and iii) interaction with miRNAs to regulate signaling events (45).

Epigenetic level. At the epigenetic level, lncRNAs have the following roles: i) The regulation of histone modifications, including acetylation, methylation and ubiquitination, among others (46); ii) participating in chromatin remodeling and conformational alterations by combining with chromatin modification complexes that are crucial for gene transcription (47); and iii) participating in gene silencing via modulating DNA methylation in the promoter region of target genes (48).

To summarize, lncRNAs participate in diverse transcriptional, post-transcriptional and epigenetic molecular mechanisms, covering regulation of chromatin structure or modification, transcription, splicing and translation, therefore regulating a multitude of physiological and pathological courses, including cell proliferation, differentiation, apoptosis, the heat shock response, cancer development and chemoresistance (49-51). Amongst these functions, the regulation of gene expression is of paramount significance in elucidating how IncRNAs promote or suppress tumorigenesis. Genome-wide studies of tumor samples have verified plentiful lncRNAs that are linked to distinct types of cancer. Dysregulated expression of lncRNAs can stimulate carcinogenesis and metastasis. However, from an overall perspective, the function of lncRNAs may not be one-sided, and could be tumor-promoting or tumor-suppressing.

\section{Expression of IncRNAs in SCLC}

Representing one of the largest classes of transcripts, lncRNAs possess highly diverse characteristics and functions. Progress in high-throughput sequencing technology has accelerated the identification of lncRNAs as key regulatory molecules participating in various cellular processes and their dysregulation in human diseases. Although only a few lncRNAs have been well described thus far, accumulating evidence suggests that lncRNAs contribute to tumor biology. Given the aforementioned difficulties, breakthroughs in SCLC research remain stagnant compared with those in other types of cancer. However, it remains worthwhile to investigate the research status of SCLC from an IncRNA point of view, as this field may open novel and optimistic windows to elucidate SCLC molecular mechanisms. In the following text, previous findings in the expression of IncRNAs in SCLC are reviewed. The roles that HOTTIP, HOTAIR, taurine upregulated gene 1 (TUG1), colon cancer-associated transcript 2 (CCAT2) and plasmacytoma variant translocation 1 (PVT1) serve in SCLC are discussed and also briefly presented in Table I. A schematic diagram of these genes in SCLC and their mechanisms is shown in Fig. 1. The dysregulations and functions of these five lncRNAs in other malignancies are also summarized, as a contrast and enlightenment to their roles in SCLC (Table II).

HOTTIP. HOTTIP, as the IncRNA encoded by the HOTTIP gene that is located at the HOXA locus, was initially identified in human fibroblasts distributed in anatomically distal regions of the body (52). Wang et al (53) verified the direct coupling of HOTTIP and the adaptor protein, WD repeat domain 5 (WDR5) to target WDR5/lysine methyltransferase $2 \mathrm{~A}$ complexes across HOXA, thereby impelling histone lysine 4 trimethylation and the transcription of various 5' HOXA genes. Multiple studies confirmed the positive correlation between the expression level of HOTTIP and HOXA genes in a variety of malignancies (52,54-56). In brief, HOTTIP could activate HOX genes by recruiting histone-modifying enzymes to suppress tumor-suppressor genes. Sun et al $(57,58)$ completed pioneering studies unveiling the underlying molecular mechanism of HOTTIP 


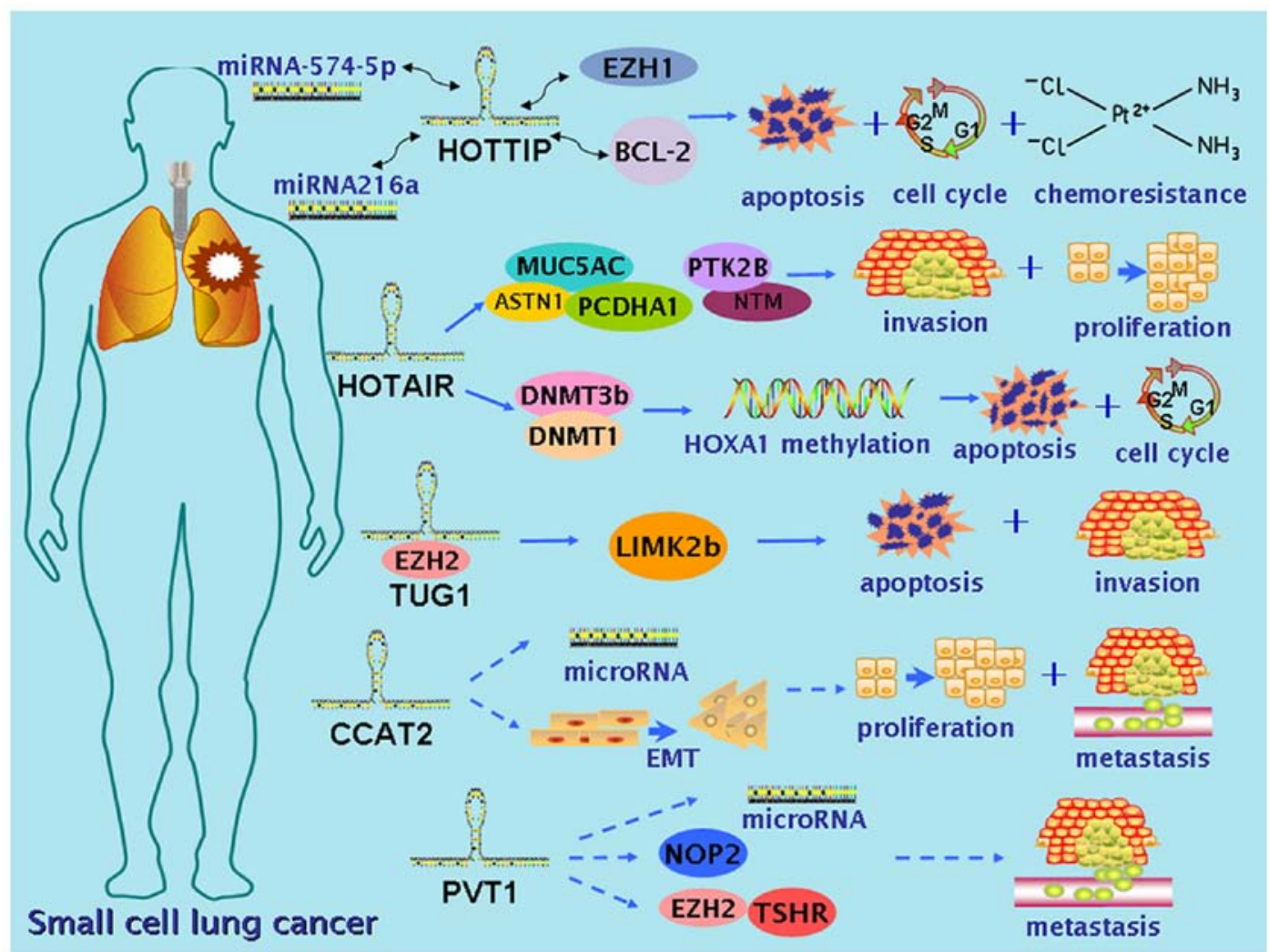

Figure 1. Schematic diagram of five lncRNAs expressed in SCLC and their mechanisms. IncRNAs exert their oncogenic effect on SCLC through interactions with various molecules involved in multiple pathways. Blue lines represent mechanisms that have been investigated in SCLC, while blue dotted lines represent mechanisms that have been investigated in other malignancies, but not yet in SCLC. Black curves with arrows at both ends represent targeting associations. Detailed information can be found in the main text. SCLC, small cell lung cancer; HOTTIP, HOXA transcript at the distal tip; EZH1, enhancer of zeste homolog 1, BCL-2, B-cell leukemia/lymphoma-2; HOTAIR, HOX transcript antisense intergenic RNA; TUG1, taurine upregulated gene 1; CCAT2, colon cancer-associated transcript 2; PVT1, plasmacytoma variant translocation 1; MUC5AC, mucin 5AC; ASTN1, astrotactin 1; PCDHA1, protocadherin $\alpha$ 1; PTK2B, protein tyrosine kinase $2 \beta$; NTM neurotrimin; DNMT3b, DNA methyltransferase $3 \beta$; DNMT1, DNA methyltransferase 1; HOXA1, homeobox A1; EZH2, enhancer of zeste homolog 2; LIMK2b, LIM domain kinase 2; EMT, epithelial-to-mesenchymal transition; NOP2, NOP2 nucleolar protein; TSHR, thyroid stimulating hormone receptor; AMPK $\beta 2$, AMP-activated protein kinase $\beta-2$; miRNA, microRNA; lncRNA, long non-coding RNA.

in SCLC utilizing a series of experiments conducted in vitro and in vivo. At first, gene expression array analysis revealed the overexpression of HOTTIP in H69 and H69R cell lines, and the result was further supported by the significant overexpression of HOTTIP, as detected by reverse transcription-quantitative polymerase chain reaction (RT-qPCR) in 50 clinical SCLC tissues prior to chemotherapy, compared with their non-cancerous counterparts. In addition, higher HOTTIP expression was significantly associated with a poorer prognosis. Manipulation of HOTTIP loss- and gain- of function experiments in SCLC cell lines also demonstrated that HOTTIP overexpression contributed to cell proliferation, as it led to a decreased number of G2-phase cells and an increased number of S-phase cells. In vivo, HOTTIP loss and gain of function experiments conducted in xenograft nude mice showed that mice with knockdown of HOTTIP had a smaller mean tumor volume in comparison to those in the negative control group. Afterwards, by employing web-based bioinformatics platform RNA22-seq (https://cm.jefferson.edu/), miR-574-5p and enhancer of zeste homolog 1 (EZH1) were predicted to possess targeted binding sites for HOTTIP, and this association was later verified by RT-qPCR. Therefore, it was assumed that HOTTIP may exert its effect on SCLC through a regulatory network of miRNA-574-5p-HOTTIP-EZH1 (57).
Notably, the hypothesis was verified by a subsequent co-transfection dual luciferase reporter assay, indicating that HOTTIP acts as an oncogene by sponging miR-574-5p to abrogate the expression of polycomb group protein EZH1 induced by miR-574-5p, thereby promoting the progression of SCLC (57). In another study by Sun et al (58), a similar experimental design was applied to investigate the role of HOTTIP in SCLC, and the association of HOTTIP with SCLC chemoresistance was also investigated, which enriched the clinical value of the study. The expression of HOTTIP and HOXA13 was markedly upregulated in SCLC cell lines and biopsy samples. Overexpression of HOTTIP impaired the anti-chemoresistance effects of etoposide, irinotecan and cisplatin toward SCLC cells in vitro and in vivo, whereas knockdown of HOTTIP exhibited a reversed effect. In addition, the finding that knockdown of HOTTIP suppressed HOXA13 expression, combined with the result of a rescue experiment by HOXA13 overexpression implied that HOTTIP exerts its function in SCLC chemoresistance and progression partly via manipulating HOXA13. Likewise, the online bioinformatics tool RNA22-seq excavated miR-216a as possessing targeted binding sites with HOTTIP, and unexpectedly, an atoptosis-related gene, B-cell leukemia/lymphoma-2 (BCL-2). Subsequent experiments confirmed that HOTTIP could 
Table II. Differential expression and mechanisms of five lncRNAs in SCLC and other malignancies.

\begin{tabular}{|c|c|c|c|c|}
\hline lncRNA & Malignancy & Dysregulation & Functions/mechanisms & (Refs.) \\
\hline \multirow[t]{5}{*}{ HOTTIP } & SCLC & Upregulation & $\begin{array}{l}\text { Chemoresistance, tumor progression. HOTTIP/miR-574-5p/EZH1 } \\
\text { network, HOTTIP/miR-216a/BCL-2 network }\end{array}$ & $(57,58)$ \\
\hline & Liver cancer & Upregulation & Metastasis and tumor progression. Regulation of HOXA13 & $(55)$ \\
\hline & Gastric cancer & Upregulation & $\begin{array}{l}\text { Cell proliferation, migration and invasion. Regulation of HOXA13 } \\
\text { and HOTTIP/miR-331-3p/HER } 2 \text { network }\end{array}$ & $(54,117)$ \\
\hline & Pancreatic cancer & Upregulation & Cell cycle, proliferation and invasion. Regulation of HOXA13 & $(56)$ \\
\hline & Prostate cancer & Upregulation & $\begin{array}{l}\text { Cell proliferation and apoptosis. Regulation of HOXA13, BAX } \\
\text { and BCL-2 }\end{array}$ & $(118)$ \\
\hline \multirow[t]{5}{*}{ HOTAIR } & SCLC & Upregulation & $\begin{array}{l}\text { Cell proliferation, lymphatic invasion, and chemoresistance. } \\
\text { Regulation of HOXA1 methylation and target genes }\end{array}$ & $(66,67)$ \\
\hline & Breast cancer & Upregulation & $\begin{array}{l}\text { Metastasis, invasion, poor prognosis, and shorter survival. } \\
\text { Regulation of Wnt signaling pathway }\end{array}$ & $(80,119)$ \\
\hline & $\begin{array}{l}\text { Colorectal } \\
\text { cancer }\end{array}$ & Upregulation & $\begin{array}{l}\text { Metastasis, poor prognosis, and low survival. Chromatin } \\
\text { modification and EMT }\end{array}$ & $(120-122)$ \\
\hline & Cervical cancer & Upregulation & $\begin{array}{l}\text { FIGO stage, aggression and lymph node metastasis. Regulation } \\
\text { of microRNA }\end{array}$ & $(123-125)$ \\
\hline & Gastric cancer & Upregulation & $\begin{array}{l}\text { Venous infiltration, lymph node metastasis, chemoresistance and } \\
\text { tumor staging. Regulation of E-cadherin, regulation of } \\
\text { PI3K/AKT/MRP1 genes }\end{array}$ & $(126-129)$ \\
\hline \multirow[t]{5}{*}{ TUG1 } & SCLC & Upregulation & $\begin{array}{l}\text { Clinical stage, chemoresistance, and shorter survival. } \\
\text { Regulation of LIMK2b }\end{array}$ & (76) \\
\hline & Liver cancer & Upregulation & $\begin{array}{l}\text { Cell proliferation, apoptosis, metastasis and glycolysis. Regulation } \\
\text { of KLF2 transcription. Regulation of AMPK } \beta 2 \text { and HK2 }\end{array}$ & $(69,130)$ \\
\hline & Gastric cancer & Upregulation & $\begin{array}{l}\text { Cell proliferation and cell cycle arrest. Regulation of } \\
\text { cyclin-dependent protein kinase inhibitors }\end{array}$ & (74) \\
\hline & $\begin{array}{l}\text { Pancreatic } \\
\text { cancer }\end{array}$ & Upregulation & Cell proliferation and cell migration. Regulation of EZH2 and EMT & $(131)$ \\
\hline & $\begin{array}{l}\text { Bladder } \\
\text { cancer }\end{array}$ & Upregulation & $\begin{array}{l}\text { Cell proliferation and apoptosis. Regulation of } \mathrm{Wnt} / \beta \text {-catenin } \\
\text { pathway }\end{array}$ & $(72,132)$ \\
\hline \multirow[t]{5}{*}{ CCAT2 } & SCLC & Upregulation & Malignant status and poor prognosis & $(85)$ \\
\hline & $\begin{array}{l}\text { Colorectal } \\
\text { cancer }\end{array}$ & Upregulation & $\begin{array}{l}\text { Lymph node metastasis, cell proliferation and differentiation. } \\
\text { Regulation of microRNA }\end{array}$ & $(77,133)$ \\
\hline & Ovarian cancer & Upregulation & $\begin{array}{l}\text { FIGO stage, cell proliferation, migration, and invasion. } \\
\text { Regulation of microRNA }\end{array}$ & $(82,134)$ \\
\hline & Prostate cancer & Upregulation & EMT, cell proliferation, invasion, and migration. Regulation of EMT & $(83)$ \\
\hline & Breast cancer & Upregulation & $\begin{array}{l}\text { Cell proliferation, invasion, chemoresistance, and poor prognosis. } \\
\text { Regulation of Wnt signaling pathway }\end{array}$ & $(80,81)$ \\
\hline \multirow[t]{5}{*}{ PVT1 } & SCLC & Upregulation & Lymph node metastasis, distal metastasis, and clinical stage & $(95)$ \\
\hline & $\begin{array}{l}\text { Gastric } \\
\text { cancer }\end{array}$ & Upregulation & $\begin{array}{l}\text { Lymph node invasion, cell proliferation and invasion. Regulation } \\
\text { of microRNA }\end{array}$ & $(89,135,136)$ \\
\hline & Livercancer & Upregulation & Cell proliferation and cell cycling. Regulation of NOP2 & $(90)$ \\
\hline & $\begin{array}{l}\text { Pancreatic } \\
\text { cancer }\end{array}$ & Upregulation & $\begin{array}{l}\text { Cell proliferation, migration, shorter survival and poor prognosis. } \\
\text { Regulation of microRNA }\end{array}$ & $(92,137)$ \\
\hline & Thyroid cancer & Upregulation & $\begin{array}{l}\text { Cell proliferation and cell cycle arrest. Regulation of EZH2 } \\
\text { and TSHR }\end{array}$ & $(91)$ \\
\hline
\end{tabular}

SCLC, small cell lung cancer; HOTTIP, HOXA transcript at the distal tip; EZH1, enhancer of zeste homolog 1, BCL-2, B-cell leukemia/lymphoma-2; HOXA13, homeobox A13; HER2, erb-b2 receptor tyrosine kinase 2; BAX, BCL-2 associated X; HOTAIR, HOX transcript antisense intergenic RNA; TUG1, taurine upregulated gene 1; CCAT2, colon cancer-associated transcript 2; PVT1, plasmacytoma variant translocation 1; HOXA1, homeobox A1; EMT, epithelial-to-mesenchymal transition; FIGO, International Federation of Gynecology and Obstetrics; PI3K, phosphatidylinositol 3-kinase; AKT, protein kinase B; MRP1, multidrug resistance-associated protein 1; LIMK2b, LIM domain kinase 2; KLF2, Kruppel like factor 2; MPK $\beta 2$, AMP-activated protein kinase subunit $\beta 2$; HK2, hexokinase 2; NOP2, NOP2 nucleolar protein; EZH2, enhancer of zeste homolog 2; TSHR, thyroid stimulating hormone receptor; miR, microRNA; lncRNA, long non-coding RNA. 
function as a competing 'sponge' through binding miR-216a, thereby diminishing its silencing effect toward BCL-2, contributing to the chemoresistance and progression of SCLC (58). Although the aforementioned findings may only be the tip of the iceberg, they widen the landscape of research into the molecular mechanism of SCLC, as a novel network composed of lncRNA, miRNA and specific cancer-related genes is put forward, providing inspiration for developing prognostic and therapeutic agents.

HOTAIR. HOTAIR is one of the most well-characterized lncRNAs and is overexpressed in certain malignancies, including breast, colorectal, hepatocellular, gastrointestinal and non-small cell lung cancer (59). First identified in 2007, HOTAIR resides in the HOXC locus. Previous reports revealed that the molecular mechanism of HOTAIR is its transcription from the HOXC gene as an antisense transcript and then binding to PRC2 (composed of EZH2, polycomb protein SUZ12 and polycomb protein EED) and lysine-specific demethylase/CoREST/REST complex as a scaffold, leading to catalyzation of trimethylation of histone $\mathrm{H} 3$ on lysine 27 (H3K27) and spontaneous demethylation of H3K4, and repression of the transcription of HOXD genes $(27,60)$. With regard to DNA methylation, EZH2, a compartment of PRC2, directly interacts with DNA methyltransferases. This interaction assists in maintaining DNA methylation and stabilizing the repression of certain genes, including various tumor suppressors (61). As targets of HOTAIR, the homeobox-containing genes are a set of regulators that transcriptionally encode DNA-binding homeodomains that participate in controlling normal development $(51,62)$. In addition, abnormal expression of HOX genes is associated with oncogenesis and paramorphia $(61,63)$. Additionally, by inducing epithelial-to-mesenchymal transition (EMT), HOTAIR associates with tumorigenesis (64). HOTAIR also triggers ubiquitin-mediated proteolysis via interaction with RNA-binding protein MEX3B and E3 ubiquitin-protein ligase DZIP3 (65). Ono et al (66) studied the association of HOTAIR with SCLC cellular processes and clinical characteristics. The study assessed HOTAIR expression in 35 surgically resected SCLC tissues and 10 SCLC cell lines, and observed that expression of HOTAIR in pure SCLC was markedly overexpressed compared with that in those combined with lung adenocarcinoma (LUAD), large cell carcinoma or large cell neuroendocrine carcinoma, and that HOTAIR overexpression was clearly associated with relapse and lymphatic invasion. In vitro experiments indicated that the expression of HOTAIR in half of the SCLC cell lines was elevated compared with that in normal cells. Knockdown of HOTAIR reduced cellular invasiveness and proliferative activity of SBC-3 cells. Gene expression analysis revealed that a reduction in HOTAIR led to upregulated expression of mucin production-related genes, including mucin 5AC, and cell adhesion-related genes, including astrotactin 1 and protocadherin $\alpha 1$, and downregulated expression of genes such as neurotrimin and protein tyrosine kinase $2 \beta$, participating in neuronal growth and signal transduction, respectively (66). Recently, Fang et al (67) investigated the role of HOTAIR expression in the chemoresistance of SCLC and its underlying mechanism. The study assessed the impact of HOTAIR on
SCLC chemoresistance in vitro and observed that HOTAIR expression was also markedly upregulated in drug-resistant cell lines compared with that in the parental cell lines. The study showed that downregulated expression of HOTAIR promoted cell cycle arrest and apoptosis to increase sensitivity to antitumor drugs, while repressing tumor growth in vivo. In addition, increased HOXA1 methylation was observed in the drug-resistant cells. An enzyme-linked immunosorbent assay revealed that a reduction of HOTAIR lessened HOXA1 methylation via reducing the expression of DNA (cytosine-5)-methyltransferase (DNMT)3b and DNMT1. RNA immunoprecipitation validated the interaction between HOXA1 and HOTAIR. Together, these findings indicated that HOTAIR mediates chemoresistance by increasing HOXA1 methylation. Hence, HOTAIR could serve as a possible target for novel therapeutics to combat chemoresistance. Based on these previous findings, lncRNA HOTAIR is involved in the relapse and lymphatic invasion in SCLC patients, and it could also act as a biomarker for prognosis and chemotherapy response, and as a therapeutic target to overcome the chemoresistance of SCLC.

TUG1. TUG1 was initially described as a spliced and polyadenylated IncRNA necessary for the development of photoreceptors in mice retina (68). Increasing evidence has demonstrated that TUG1 serves a crucial role in a number of human tumors, including hepatocellular carcinoma, osteosarcoma, glioma, esophageal, gastric and bladder cancer (69-74). Aberrant expression of PRC2-related lncRNAs is involved in tumorigenesis and progression. In a previous study, TUG1 was found to be induced by $\mathrm{p} 53$, prior to binding to PCR2 and influencing certain genes involved in the modulation of mitosis, spindle construction and cell-cycle phasing (34). Yang et al (75) revealed that a combination of methylated PRC2 and TUG1 manipulates the relocation of growth-control genes between interchromatin granules and polycomb bodies in response to growth signals, therefore portraying a role that TUG1 serves in the relocation of transcription units to coordinate gene expression (75). Niu et al (76) investigated the functions of TUG1 in the cell proliferation and chemoresistance of SCLC, and its underlying molecular mechanism (76). The study analyzed TUG1 expression in tissue samples from SCLC patients $(n=33)$ who had undergone biopsy or bronchofiberscopy, and elevated TUG1 expression was found in cancerous tissues compared with that in adjacent non-cancerous tissues. Statistical analysis showed that higher expression of TUG1 was associated with shorter survival time, advanced clinical stage and cigarette smoking. In vitro Cell Counting Kit- 8 and colony formation assays indicated that silencing TUG1 markedly reduced cell growth. The results from flow cytometry analysis conducted to assess the effect of TUG1 on cell apoptosis suggested that knockdown of TUG1 promoted apoptosis and led to a significant accumulation of G1-phase cells, and that downregulated TUG1 expression increased apoptosis in H44DDP and H69AR cell lines exposed to anticancer drugs. The chemoresistance-inducing ability of TUG1 in vivo was further investigated using a mouse xenograft model, and the result was consistent with that of the in vitro experiment. Moreover, TUG1 could modulate LIM domain kinase 2 expression through binding with $\mathrm{EZH} 2$, and 
subsequently led to increased cell growth and chemoresistance in SCLC. Outcomes of this study could be guidance to the development of innovative TUG1-directed prognostic and therapeutic strategies.

CCAT2. CCAT2 was first introduced in 2013 as an lncRNA located in the $8 \mathrm{q} 24$ gene desert region, and it possesses a tumor-related single nucleotide polymorphism rs6983276. Additionally, overexpression of CCAT2 in colon cancer was observed, and it was considered to serve an oncogenic role, promoting colorectal cancer cell proliferation and motility, metastasis and chromosomal instability by regulating myc and Wnt pathways (77). A CCAT2 genetic polymorphism, rs6983267, is associated with platinum-based chemotherapy sensitivity in lung cancer patients (78). Since its discovery, the oncogenic role of CCAT 2 has been increasingly demonstrated in different tumors, including gastric, breast, lung, liver, colon, cervical, ovarian, bladder, prostate and esophageal cancer (79-84). The stimulatory effects on the Wnt/ $\beta$-catenin signaling pathway, cancer metabolism and EMT may underlie its oncogenic action (79). CCAT2 is upregulated in an estimated two-thirds of breast cancer patients (80). High CCAT2 expression was associated with a poor curative effect from cyclophosphamide/methotrexate/fluorouracil-containing adjuvant chemotherapy in breast cancer patients with lymph node metastasis (80). Chen et al (85) detected CCAT2 expression in 102 human SCLC tissues, 15 paired non-tumor tissues, SCLC cell lines (DMS-53 and H446) and a normal bronchial epithelial cell line (16HBE). The association between clinicopathological factors and CCAT2 expression was subsequently analyzed. The study reported that CCAT2 level was significantly overexpressed in SCLC tissue and cell lines compared with that in normal lung tissues. Subgroup analyses also indicated that higher expression of CCAT2 was correlated with malignant status and poor prognosis in SCLC patients. Moreover, knockdown of CCAT2 to inhibit SCLC cell growth and metastasis in vitro was observed. To conclude, CCAT2 may serve as an oncogene and a negative prognostic indicator in SCLC.

PVT1. PVT1 is an 1ncRNA homologous to the mouse plasmacytoma variant translocation gene (Pvt1), which was first identified as being frequently involved in a variant translocation in plasmacytoma in the mid-80s in mice $(86,87)$. Soon after, the PVT1 locus emerged as a site of variant translocations in Burkitt lymphoma. Subsequent studies support the role of PVT1 as a cancer risk locus in relation to the well-known myc oncogene (88). PVT1 presents the capacity to facilitate cell growth and suppress cell apoptosis in the tumorigenesis of various types of cancer, including gastric (89), liver (90), thyroid (91) and pancreatic (92) cancer, and non-small cell lung cancer (93). The expression of PVT1 in tumor samples of these types of cancer is elevated. In vitro and in vivo experiments conducted by Wang et al (90) demonstrated that PVT1 promotes cell proliferation, cell cycling and the acquisition of stem cell-like properties in hepatocellular carcinoma cell by stabilizing NOP2 nucleolar protein (90). However, the underlying mechanisms of the functional exertion of PVT1 and its interaction with downstream targets remain largely unknown. Partially known molecular functions of PVT1 can be categorized into three key pathways: Partaking in DNA rearrangement, encoding microRNAs and intercommunicating with myc (94). Recently, Huang et al (95) first identified the role of PVT1 in SCLC. In the study, PVT1 expression was detected in SCLC tissues, paired normal gastric tissues and two SCLC cell lines. Meanwhile, the association of PVT1 expression levels with clinical features of 120 enrolled SCLC patients was analyzed. RT-PCR analysis showed that PVT1 expression was significantly higher in SCLC tissues and cell lines than in their normal counterparts, and positive correlations between PVT1 overexpression and the status of clinical stage, lymph node metastasis and distal metastasis in SCLC were noted. Furthermore, multivariate analysis revealed that PVT overexpression could be an independent prognostic biomarker for the survival of SCLC patients. Cell migration and invasion were significantly suppressed in vitro by silencing of PVT1 in SCLC. To conclude, PVT1 possesses the potency to be a novel marker and a prospect to develop targeted therapy for SCLC. However, further investigations are required for thorough elucidation of the molecular mechanism of PVT1 in SCLC.

Thus far, the present review has summarized and discussed five lncRNAs (HOTTIP, HOTAIR, TUG1, CCAT2 and PVT1) involved in SCLC. However, these lncRNAs are also involved in NSCLC, which accounts for $\sim 85 \%$ of all lung cancer cases. It is of merit to include information on the roles that these IncRNAs serve in NSCLC, as a contrast and possibly, enlightenment. HOTTIP was reported to be significantly upregulated in NSCLC and to function as an oncogene by regulating HOXA13, which coincides with the findings observed in other malignancies, implying that HOXA13 is a key element through which HOTTIP promotes carcinogenesis (96). Moreover, overexpression of HOTTIP was found to motivate LUAD cell proliferation and chemoresistance via regulating the protein kinase $\mathrm{B}$ (AKT) signaling pathway (97). As for HOTAIR, multiple studies also demonstrated its overexpression in NSCLC, and it is involved in the initiation and development of NSCLC through interacting with unc-51-like autophagy-activating kinase 1 to suppress autophagy (98), targeting caveolin 1 (99) and miR-613 (100). Based on the available literature, there is controversy with regard to the expression of TUG1 in NSCLC. Studies by Lin et al (101) and Zhang et al (102) revealed that TUG1 was downregulated in NSCLC, while a study by Liu et al (103) showed that it was upregulated. According to the study by Liu et al, TUG1 could inhibit apoptosis by silencing BCL-2 associated X via interacting with EZH2 (103). TUG1 RNA could target PRC2 in the promotor region of CUGBP Elav-like family member 1 (CELF1) and CELF1 expression was therefore negatively regulated (101). Zhang et al (102) suggested that TUG1 acted as a growth regulator in NSCLC partly through controlling HOXB7. CCAT2 exerted overexpression in NSCLC $(104,105)$, and could promote oncogenesis via overexpression of zinc finger and BTB domain containing 7A (104). With regard to PVT1, it is of note that accumulating recent studies (106-109) investigated the roles of upregulated PVT1 in NSCLC via the ceRNA-regulated network, which is a trending hotspot in the research field. PVT1 was demonstrated to exert its oncogenic functions by sponging miR199a5p (106), miR-126 (107), miR-497 (108) and miR-195 (109). 


\section{Conclusions and future directions}

SCLC is a fatal disease with an aggressive and brutal nature; it comprises $\sim 15 \%$ of all lung cancer cases. The management of SCLC remains challenging, while disease outcome has remained poor, mainly due to limited options for effective treatment. The majority of the cases are at an irreversible advanced stage when diagnosed and rapidly develop treatment resistance despite a high success rate of initial chemotherapy and radiation. The pathogenesis of SCLC has been investigated by researchers across the world; nevertheless, the implicit molecular mechanism remains mostly unidentified. In light of next-generation sequencing techniques and bioinformatics tools, IncRNAs have been shown to exert distinguishable functions in a broad range of human diseases, including the most concerning types of cancer. Although great discoveries and advances in cancer pathogenesis and therapeutics have been made over the decade, the elucidation of the SCLC molecular mechanism and its frontline treatment have developed slowly due to obstacles from various aspects, including difficulty in sample collection, research funding, late diagnosis, rapid progression and chemoresistance. Investigation into the role of lncRNAs in SCLC is underway, yet no IncRNAs have been extensively investigated, let alone clinically utilized for prognosis, diagnosis or therapeutic design. According to the available published literature, the current research state of SCLC is relatively superficial compared with that of NSCLC. Thus, more research is urgently required.

Despite the aforementioned challenges, there have been certain notable novel findings that have the potential to advance the field. Given the scarcity of SCLC tissues, a multidisciplinary, interoperable, cross-institutional approach is required to collect adequate SCLC tissues for more translational research projects. Emerging techniques, including next-generation sequencing and bioinformatics, have created opportunities to conduct larger scale and deeper studies on SCLC. The past decade has witnessed the emergence of lncRNAs involved in various types of cancer. For example, lncRNA prostate cancer antigen 3 and lncRNA highly upregulated in liver cancer can be detected in prostate and liver cancer, respectively, and serve as sensitive diagnostic markers $(110,111)$. As an intensively studied lncRNA, lncRNA metastasis-associated lung adenocarcinoma transcript 1 is found to be involved in multiple malignancies, including lung, colon, breast and liver cancer, indicating its general participation in cancer cell proliferation (112). Overexpression of lncRNA antisense noncoding RNA in the INK4 locus is observed in a number of types of cancer and is associated with a poor prognosis in gastric and prostate cancer (113). IncRNA CCAT1 could be used as a clinically detectable marker to predict the therapeutic responsiveness of bromodomain and extraterminal inhibitors in patients with colorectal cancer (114). IncRNA maternally expressed gene 3, which acts as a tumor-suppressor via promoting p53 accumulation and recruiting $\mathrm{PRC} 2$, is downregulated in multiple primary human tumors (115). As these IncRNAs have been verified as promising predictive markers for diagnosis, prognosis and chemotherapy sensitivity in cancer patients, they also have the potential to lead to a greater understanding of
SCLC tumorigenesis and chemoresistance, and could serve as efficient therapeutic targets. The diagnostic sensitivity and specificity may be enhanced by joint detection of disparate lncRNAs, and this may become particularly useful in non-invasive screening for early-stage SCLC patients. The functional roles of lncRNAs involve diverse signaling pathways and investigation into these pathways may yield crucial signaling targets that could be blocked to impede tumor progression. Signaling pathways frequently altered in cancer include phosphoinositide 3-kinase/AKT, Kirsten rat sarcoma viral oncogene homolog/V-raf murine sarcoma b-viral oncogene homolog B1, retrovirus-associated DNA sequences/mitogen-activated protein kinase, EGFR, fibroblast growth factor receptor, Wnt and myc, among others (116). Currently, among nearly 20,000 identified lncRNAs, only five have been investigated in SCLC. Therefore, more efforts should be put into this field of great potential. As a large genetic information treasury and a potential opening to combat diseases, IncRNAs will play no small part in identifying SCLC mechanisms.

\section{Acknowledgements}

Not applicable.

\section{Funding}

The present study was supported by funds from the National Natural Science Foundation of China (grant no. NSFC81560469 and NSFC81360327), the Natural Science Foundation of Guangxi, China (grant no. 2015GXNSFCA139009, 2016GXNSFAA380255 and 2017GXNSFAA198016) and the Guangxi Medical University Training Program for Distinguished Young Scholars (grant no. 2017).

\section{Availability of data and materials}

Not applicable.

\section{Authors' contributions}

TTL contributed to the literature retrieval and manuscript preparation. $\mathrm{RQH}$ and $\mathrm{JM}$ contributed to the manuscript modification and commented on multiple aspects of the manuscript. ZYL, XHH and GC jointly supervised the construction of the study, and contributed to the design and approval of the final version of the manuscript.

\section{Ethics approval and consent to participate}

Not applicable.

\section{Patient consent for publication}

Not applicable.

\section{Competing interests}

The authors declare that they have no competing interests. 


\section{References}

1. van Meerbeeck JP, Fennell DA and De Ruysscher DK: Small-cell lung cancer. Lancet 378: 1741-1755, 2011.

2. Barnes H, See K, Barnett S and Manser R: Surgery for limited-stage small-cell lung cancer. Cochrane Database Syst Rev 4: CD011917, 2017.

3. Sabari JK, Lok BH, Laird JH, Poirier JT and Rudin CM: Unravelling the biology of SCLC: Implications for therapy. Nat Rev Clin Oncol 14: 549-561, 2017.

4. Pillai RN and Owonikoko TK: Small cell lung cancer: Therapies and targets. Semin Oncol 41: 133-142, 2014.

5. Byers LA and Rudin CM: Small cell lung cancer: Where do we go from here? Cancer 121: 664-672, 2015.

6. Dolly SO, Collins DC, Sundar R, Popat S and Yap TA: Advances in the development of molecularly targeted agents in non-small-cell lung cancer. Drugs 77: 813-827, 2017.

7. Seeber A, Leitner C, Philipp-Abbrederis K, Spizzo G and Kocher F: What's new in small cell lung cancer-extensive disease? An overview on advances of systemic treatment in 2016. Future Oncol 13: 1427-1435, 2017.

8. Djebali S, Davis CA, Merkel A, Dobin A, Lassmann T, Mortazavi A, Tanzer A, Lagarde J, Lin W, Schlesinger F, et al: Landscape of transcription in human cells. Nature 489: 101-108, 2012.

9. George J, Lim JS, Jang SJ, Cun Y, Ozretić L, Kong G, Leenders F, Lu X, Fernández-Cuesta L, Bosco G, et al: Comprehensive genomic profiles of small cell lung cancer. Nature 524: 47-53, 2015.

10. Pleasance ED, Stephens PJ, O'Meara S, McBride DJ, Meynert A, Jones D, Lin ML, Beare D, Lau KW, Greenman C, et al: A small-cell lung cancer genome with complex signatures of tobacco exposure. Nature 463: 184-190, 2010.

11. Kung JT, Colognori D and Lee JT: Long noncoding RNAs: Past, present, and future. Genetics 193: 651-669, 2013.

12. Ulitsky I and Bartel DP: LincRNAs: Genomics, evolution, and mechanisms. Cell 154: 26-46, 2013.

13. Gibb EA, Brown CJ and Lam WL: The functional role of long non-coding RNA in human carcinomas. Mol Cancer 10: 38, 2011.

14. Huang J, Peng J and Guo L: Non-coding RNA: A new tool for the diagnosis, prognosis, and therapy of small cell lung cancer. J Thorac Oncol 10: 28-37, 2015.

15. Kwok ZH and Tay Y: Long noncoding RNAs: Lincs between human health and disease. Biochem Soc Trans 45: 805-812, 2017.

16. Ohno S: So much 'junk' DNA in our genome. Brookhaven Symp Biol 23: 366-370, 1972.

17. Spornraft M, Kirchner B, Pfaffl MW and Riedmaier I: Comparison of the miRNome and piRNome of bovine blood and plasma by small RNA sequencing. Biotechnol Lett 37: 1165-1176, 2015.

18. Busch H, Reddy R, Rothblum L and Choi YC: SnRNAs, SnRNPs, and RNA processing. Annu Rev Biochem 51: 617-654, 1982.

19. Ota T, Suzuki Y, Nishikawa T, Otsuki T, Sugiyama T, Irie R, Wakamatsu A, Hayashi K, Sato H, Nagai K, et al: Complete sequencing and characterization of 21,243 full-length human cDNAs. Nat Genet 36: 40-45, 2004

20. Bertone P, Stolc V, Royce TE, Rozowsky JS, Urban AE, Zhu X, Rinn JL, Tongprasit W, Samanta M, Weissman S, et al: Global identification of human transcribed sequences with genome tiling arrays. Science 306: 2242-2246, 2004.

21. Okazaki Y, Furuno M, Kasukawa T, Adachi J, Bono H, Kondo S, Nikaido I, Osato N, Saito R, Suzuki H, et al: Analysis of the mouse transcriptome based on functional annotation of 60,770 full-length cDNAs. Nature 420: 563-573, 2002.

22. Hon CC, Ramilowski JA, Harshbarger J, Bertin N, Rackham OJ, Gough J, Denisenko E, Schmeier S, Poulsen TM, Severin J, et al: An atlas of human long non-coding RNAs with accurate 5' ends. Nature 543: 199-204, 2017

23. Hombach S and Kretz M: Non-coding RNAs: Classification, biology and functioning. Adv Exp Med Biol 937: 3-17, 2016.

24. Schmitt AM and Chang HY: Long noncoding RNAs in cancer pathways. Cancer Cell 29: 452-463, 2016.

25. Wang KC and Chang HY: Molecular mechanisms of long noncoding RNAs. Mol Cell 43: 904-914, 2011

26. Wang KC, Helms JA and Chang HY: Regeneration, repair and remembering identity: The three Rs of Hox gene expression. Trends Cell Biol 19: 268-275, 2009.
27. Rinn JL, Kertesz M, Wang JK, Squazzo SL, Xu X, Brugmann SA, Goodnough LH, Helms JA, Farnham PJ, Segal E, et al: Functional demarcation of active and silent chromatin domains in human HOX loci by noncoding RNAs. Cell 129: 1311-1323, 2007.

28. Hung T, Wang Y, Lin MF, Koegel AK, Kotake Y, Grant GD, Horlings HM, Shah N, Umbricht C, Wang P, et al: Extensive and coordinated transcription of noncoding RNAs within cell-cycle promoters. Nat Genet 43: 621-629, 2011.

29. Plath K, Mlynarczyk-Evans S, Nusinow DA and Panning B: Xist RNA and the mechanism of X chromosome inactivation. Annu Rev Genet 36: 233-278, 2002.

30. Lee JT: The $X$ as model for RNA's niche in epigenomic regulation. Cold Spring Harb Perspect Biol 2: a003749, 2010.

31. Wutz A, Rasmussen TP and Jaenisch R: Chromosomal silencing and localization are mediated by different domains of Xist RNA. Nat Genet 30: 167-174, 2002.

32. Gupta RA, Shah N, Wang KC, Kim J, Horlings HM, Wong DJ, Tsai MC, Hung T, Argani P, Rinn JL, et al: Long non-coding RNA HOTAIR reprograms chromatin state to promote cancer metastasis. Nature 464: 1071-1076, 2010.

33. Zhao J, Ohsumi TK, Kung JT, Ogawa Y, Grau DJ, Sarma K, Song JJ, Kingston RE, Borowsky M and Lee JT: Genome-wide identification of polycomb-associated RNAs by RIP-seq. Mol Cell 40: 939-953, 2010.

34. Khalil AM, Guttman M, Huarte M, Garber M, Raj A, Rivea Morales D, Thomas K, Presser A, Bernstein BE, van Oudenaarden A, et al: Many human large intergenic noncoding RNAs associate with chromatin-modifying complexes and affect gene expression. Proc Natl Acad Sci USA 106: 11667-11672, 2009.

35. Spitale RC, Tsai MC and Chang HY: RNA templating the epigenome: Long noncoding RNAs as molecular scaffolds. Epigenetics 6: 539-543, 2011.

36. Collins K: Physiological assembly and activity of human telomerase complexes. Mech Ageing Dev 129: 91-98, 2008.

37. Chen JL and Greider CW: Telomerase RNA structure and function: Implications for dyskeratosis congenita. Trends Biochem Sci 29: 183-192, 2004

38. Moretti F, Thermann R and Hentze MW: Mechanism of translational regulation by miR-2 from sites in the 5 ' untranslated region or the open reading frame. RNA 16: 2493-2502, 2010.

39. Ørom UA, Nielsen FC and Lund AH: MicroRNA-10a binds the 5'UTR of ribosomal protein mRNAs and enhances their translation. Mol Cell 30: 460-471, 2008

40. Hu X, Feng Y, Zhang D, Zhao SD, Hu Z, Greshock J, Zhang Y, Yang L, Zhong X, Wang LP, et al: A functional genomic approach identifies $F A L 1$ as an oncogenic long noncoding RNA that associates with BMI1 and represses p21 expression in cancer. Cancer Cell 26: 344-357, 2014.

41. Yin Y, Yan P, Lu J, Song G, Zhu Y, Li Z, Zhao Y, Shen B, Huang $\mathrm{X}$, Zhu $\mathrm{H}$, et al: Opposing roles for the lncRNA Haunt and its genomic locus in regulating HOXA gene activation during embryonic stem cell differentiation. Cell Stem Cell 16: 504-516, 2015.

42. Cesana M, Cacchiarelli D, Legnini I, Santini T, Sthandier O, Chinappi M, Tramontano A and Bozzoni I: A long noncoding RNA controls muscle differentiation by functioning as a competing endogenous RNA. Cell 147: 358-369, 2011.

43. Tripathi V, Ellis JD, Shen Z, Song DY, Pan Q, Watt AT, Freier SM, Bennett CF, Sharma A, Bubulya PA, et al: The nuclear-retained noncoding RNA MALAT1 regulates alternative splicing by modulating SR splicing factor phosphorylation. Mol Cell 39: 925-938, 2010

44. Yuan JH, Yang F, Wang F, Ma JZ, Guo YJ, Tao QF, Liu F, Pan W, Wang TT, Zhou CC, et al: A long noncoding RNA activated by TGF-beta promotes the invasion-metastasis cascade in hepatocellular carcinoma. Cancer Cell 25: 666-681, 2014

45. Steck E, Boeuf S, Gabler J, Werth N, Schnatzer P, Diederichs S and Richter W: Regulation of H19 and its encoded microRNA-675 in osteoarthritis and under anabolic and catabolic in vitro conditions. J Mol Med 90: 1185-1195, 2012.

46. Houseley J, Rubbi L, Grunstein M, Tollervey D and Vogelauer M: A ncRNA modulates histone modification and mRNA induction in the yeast GAL gene cluster. Mol Cell 32: 685-695, 2008.

47. Hainer SJ, Gu W, Carone BR, Landry BD, Rando OJ, Mello CC and Fazzio TG: Suppression of pervasive noncoding transcription in embryonic stem cells by esBAF. Genes Dev 29: 362-378, 2015. 
48. Berghoff EG, Clark MF, Chen S, Cajigas I, Leib DE and Kohtz JD: Evf2 (Dlx6as) lncRNA regulates ultraconserved enhancer methylation and the differential transcriptional control of adjacent genes. Development 140: 4407-4416, 2013.

49. Geisler S and Coller J: RNA in unexpected places: Long non-coding RNA functions in diverse cellular contexts. Nat Rev Mol Cell Biol 14: 699-712, 2013.

50. Chen G, Wang Z, Wang D, Qiu C, Liu M, Chen X, Zhang Q, Yan G and Cui Q: LncRNADisease: A database for long-non-coding RNA-associated diseases. Nucleic Acids Res 41: D983-D986, 2013.

51. Ponting CP, Oliver PL and Reik W: Evolution and functions of long noncoding RNAs. Cell 136: 629-641, 2009.

52. Lian Y, Cai Z, Gong H, Xue S, Wu D and Wang K: HOTTIP: A critical oncogenic long non-coding RNA in human cancers. Mol biosyst 12: 3247-3253, 2016.

53. Wang KC, Yang YW, Liu B, Sanyal A, Corces-Zimmerman R, Chen Y, Lajoie BR, Protacio A, Flynn RA, Gupta RA, et al: A long noncoding RNA maintains active chromatin to coordinate homeotic gene expression. Nature 472: 120-124, 2011.

54. Chang S, Liu J, Guo S, He S, Qiu G, Lu J, Wang J, Fan L, Zhao W and Che X: HOTTIP and HOXA13 are oncogenes associated with gastric cancer progression. Oncol Rep 35: 3577-3585, 2016.

55. Quagliata L, Matter MS, Piscuoglio S, Arabi L, Ruiz C, Procino A, Kovac M, Moretti F, Makowska Z, Boldanova T, et al: Long noncoding RNA HOTTIP/HOXA13 expression is associated with disease progression and predicts outcome in hepatocellular carcinoma patients. Hepatology 59: 911-923, 2014.

56. Li Z, Zhao X, Zhou Y, Liu Y, Zhou Q, Ye H, Wang Y, Zeng J, Song Y, Gao W, et al: The long non-coding RNA HOTTIP promotes progression and gemcitabine resistance by regulating HOXA13 in pancreatic cancer. J Transl Med 13: 84, 2015.

57. Sun Y, Zhou Y, Bai Y, Wang Q, Bao J, Luo Y, Guo Y and Guo L: A long non-coding RNA HOTTIP expression is associated with disease progression and predicts outcome in small cell lung cancer patients. Mol Cancer 16: 162, 2017.

58. Sun Y, Hu B, Wang Q, Ye M, Qiu Q, Zhou Y, Zeng F, Zhang X, Guo Y and Guo L: Long non-coding RNA HOTTIP promotes BCL-2 expression and induces chemoresistance in small cell lung cancer by sponging miR-216a. Cell Death Dis 9: 85, 2018.

59. Bhan A, Soleimani $M$ and Mandal SS: Long noncoding RNA and cancer: A new paradigm. Cancer Res 77: 3965-3981, 2017.

60. Tsai MC, Manor O, Wan Y, Mosammaparast N, Wang JK, Lan F, Shi Y, Segal E and Chang HY: Long noncoding RNA as modular scaffold of histone modification complexes. Science 329: 689-693, 2010

61. Sun G, Alzayady K, Stewart R, Ye P, Yang S, Li W and Shi Y: Histone demethylase LSD1 regulates neural stem cell proliferation. Mol Cell Biol 30: 1997-2005, 2010.

62. Mercer TR, Dinger ME and Mattick JS: Long non-coding RNAs: Insights into functions. Nat Rev Genet 10: 155-159, 2009.

63. Tsai MC, Spitale RC and Chang HY: Long intergenic noncoding RNAs: New links in cancer progression. Cancer Res 71: 3-7, 2011.

64. Pádua Alves C, Fonseca AS, Muys BR, de Barros E Lima Bueno R, Bürger MC, de Souza JE, Valente V, Zago MA and Silva WA Jr: Brief report: The lincRNA Hotair is required for epithelial-to-mesenchymal transition and stemness maintenance of cancer cell lines. Stem Cells 31: 2827-2832, 2013.

65. Yoon JH, Abdelmohsen K, Kim J, Yang X, Martindale JL, Tominaga-Yamanaka K, White EJ, Orjalo AV, Rinn JL, Kreft SG, et al: Scaffold function of long non-coding RNA HOTAIR in protein ubiquitination. Nat Commun 4: 2939, 2013

66. Ono H, Motoi N, Nagano H, Miyauchi E, Ushijima M, Matsuura M, Okumura S, Nishio M, Hirose T, Inase N, et al: Long noncoding RNA HOTAIR is relevant to cellular proliferation, invasiveness, and clinical relapse in small-cell lung cancer. Cancer Med 3: 632-642, 2014.

67. Fang S, Gao H, Tong Y, Yang J, Tang R, Niu Y, Li M and Guo L: Long noncoding RNA-HOTAIR affects chemoresistance by regulating HOXA1 methylation in small cell lung cancer cells Lab Invest 96: 60-68, 2016.

68. Young TL, Matsuda T and Cepko CL: The noncoding RNA taurine upregulated gene 1 is required for differentiation of the murine retina. Curr Biol 15: 501-512, 2005.

69. Huang MD, Chen WM, Qi FZ, Sun M, Xu TP, Ma P and Shu YQ: Long non-coding RNA TUG1 is up-regulated in hepatocellular carcinoma and promotes cell growth and apoptosis by epigenetically silencing of KLF2. Mol Cancer 14: 165, 2015.
70. Ma B, Li M, Zhang L, Huang M, Lei JB, Fu GH, Liu CX, Lai QW Chen QQ and Wang YL: Upregulation of long non-coding RNA TUG1 correlates with poor prognosis and disease status in osteosarcoma. Tumour Biol 37: 4445-4455, 2016.

71. Liu Q, Sun S, Yu W, Jiang J, Zhuo F, Qiu G, Xu S and Jiang X: Altered expression of long non-coding RNAs during genotoxic stress-induced cell death in human glioma cells. J Neurooncol 122: 283-292, 2015.

72. Han Y, Liu Y, Gui Y and Cai Z: Long intergenic non-coding RNA TUG1 is overexpressed in urothelial carcinoma of the bladder. J Surg Oncol 107: 555-559, 2013.

73. Xu Y, Wang J, Qiu M, Xu L, Li M, Jiang F, Yin R and Xu L: Upregulation of the long noncoding RNA TUG1 promotes proliferation and migration of esophageal squamous cell carcinoma. Tumour Biol 36: 1643-1651, 2015.

74. Zhang E, He X, Yin D, Han L, Qiu M, Xu T, Xia R, Xu L, Yin R and De W: Increased expression of long noncoding RNA TUG1 predicts a poor prognosis of gastric cancer and regulates cell proliferation by epigenetically silencing of p57. Cell Death Dis 7: e2109, 2016.

75. Yang L, Lin C, Liu W, Zhang J, Ohgi KA, Grinstein JD, Dorrestein PC and Rosenfeld MG: ncRNA- and Pc2 methylation-dependent gene relocation between nuclear structures mediates gene activation programs. Cell 147: 773-788, 2011.

76. Niu Y, Ma F, Huang W, Fang S, Li M, Wei T and Guo L: Long non-coding RNA TUG1 is involved in cell growth and chemoresistance of small cell lung cancer by regulating LIMK $2 b$ via EZH2. Mol Cancer 16: 5, 2017.

77. Ling H, Spizzo R, Atlasi Y, Nicoloso M, Shimizu M, Redis RS Nishida N, Gafà R, Song J, Guo Z, et al: CCAT2, a novel noncoding RNA mapping to $8 \mathrm{q} 24$, underlies metastatic progression and chromosomal instability in colon cancer. Genome Res 23: 1446-1461, 2013.

78. Gong WJ, Yin JY, Li XP, Fang C, Xiao D, Zhang W, Zhou HH, Li $X$ and Liu ZQ: Association of well-characterized lung cancer lncRNA polymorphisms with lung cancer susceptibility and platinum-based chemotherapy response. Tumour Biol 37: 8349-8358, 2016.

79. Xin Y, Li Z, Zheng H, Chan MTV and Ka Kei Wu W: CCAT2: A novel oncogenic long non-coding RNA in human cancers. Cell Prolif 50, 2017.

80. Redis RS, Sieuwerts AM, Look MP, Tudoran O, Ivan C, Spizzo R, Zhang X, de Weerd V, Shimizu M, Ling H, et al: CCAT2, a novel long non-coding RNA in breast cancer: Expression study and clinical correlations. Oncotarget 4: 1748-1762, 2013.

81. Cai Y, He J and Zhang D: Long noncoding RNA CCAT2 promotes breast tumor growth by regulating the Wnt signaling pathway. Onco Targets Ther 8: 2657-2664, 2015.

82. Huang S, Qing C, Huang Z and Zhu Y: The long non-coding RNA CCAT2 is up-regulated in ovarian cancer and associated with poor prognosis. Diagn Pathol 11: 49, 2016.

83. Zheng J, Zhao S, He X, Zheng Z, Bai W, Duan Y, Cheng S, Wang J, Liu $X$ and Zhang G: The up-regulation of long non-coding RNA CCAT2 indicates a poor prognosis for prostate cancer and promotes metastasis by affecting epithelial-mesenchymal transition. Biochem Biophys Res Commun 480: 508-514, 2016.

84. Wang CY, Hua L, Yao KH, Chen JT, Zhang JJ and Hu JH: Long non-coding RNA CCAT2 is up-regulated in gastric cancer and associated with poor prognosis. Int J Clin Exp Pathol 8: 779-785, 2015.

85. Chen S, Wu H, Lv N, Wang H, Wang Y, Tang Q, Shao H and Sun C: LncRNA CCAT2 predicts poor prognosis and regulates growth and metastasis in small cell lung cancer. Biomed Pharmacother 82: 583-588, 2016

86. Webb E, Adams JM and Cory S: Variant $(6 ; 15)$ translocation in a murine plasmacytoma occurs near an immunoglobulin kappa gene but far from the myc oncogene. Nature 312: 777-779, 1984.

87. Cory S, Graham M, Webb E, Corcoran L and Adams JM: Variant $(6 ; 15)$ translocations in murine plasmacytomas involve a chromosome 15 locus at least $72 \mathrm{~kb}$ from the c-myc oncogene. EMBO J 4: 675-681, 1985.

88. Colombo T, Farina L, Macino G and Paci P: PVT1: A rising star among oncogenic long noncoding RNAs. Biomed Res Int 2015: 304208, 2015.

89. Ding J, Li D, Gong M, Wang J, Huang X, Wu T and Wang C: Expression and clinical significance of the long non-coding RNA PVT1 in human gastric cancer. Onco Targets Ther 7: 1625-1630, 2014. 
90. Wang F, Yuan JH, Wang SB, Yang F, Yuan SX, Ye C, Yang N, Zhou WP, Li WL, Li W, et al: Oncofetal long noncoding RNA PVT1 promotes proliferation and stem cell-like property of hepatocellular carcinoma cells by stabilizing NOP2. Hepatology 60 : 1278-1290, 2014.

91. Zhou Q, Chen J, Feng J and Wang J: Long noncoding RNA PVT1 modulates thyroid cancer cell proliferation by recruiting EZH2 and regulating thyroid-stimulating hormone receptor (TSHR). Tumour Biol 37: 3105-3113, 2016.

92. Huang C, Yu W, Wang Q, Cui H, Wang Y, Zhang L, Han F and Huang T: Increased expression of the lncRNA PVT1 is associated with poor prognosis in pancreatic cancer patients. Minerva Med 106: 143-149, 2015

93. Cui D, Yu CH, Liu M, Xia QQ, Zhang YF and Jiang WL: Long non-coding RNA PVT1 as a novel biomarker for diagnosis and prognosis of non-small cell lung cancer. Tumour Biol 37: 4127-4134, 2016.

94. Cui M, You L, Ren X, Zhao W, Liao Q and Zhao Y: Long non-coding RNA PVT1 and cancer. Biochem Biophys Res Commun 471: 10-14, 2016

95. Huang C, Liu S, Wang H, Zhang Z, Yang Q and Gao F: LncRNA PVT1 overexpression is a poor prognostic biomarker and regulates migration and invasion in small cell lung cancer. Am J Transl Res 8: 5025-5034, 2016.

96. Sang Y, Zhou F, Wang D, Bi X, Liu X, Hao Z, Li Q and Zhang W: Up-regulation of long non-coding HOTTIP functions as an oncogene by regulating HOXA13 in non-small cell lung cancer. Am J Transl Res 8: 2022-2032, 2016.

97. Zhang GJ, Song W and Song Y: Overexpression of HOTTIP promotes proliferation and drug resistance of lung adenocarcinoma by regulating AKT signaling pathway. Eur Rev Med Pharmacol Sci 21: 5683-5690, 2017

98. Yang Y, Jiang C, Yang Y, Guo L, Huang J, Liu X, Wu C and Zou J: Silencing of LncRNA-HOTAIR decreases drug resistance of non-small cell lung cancer cells by inactivating autophagy via suppressing the phosphorylation of ULK1. Biochem Biophys Res Commun 497: 1003-1010, 2018.

99. Liu W, Yin NC, Liu H and Nan KJ: Cav-1 promote lung cancer cell proliferation and invasion through $\operatorname{lncRNA}$ HOTAIR. Gene 641: 335-340, 2018.

100. Jiang C, Yang Y, Yang Y, Guo L, Huang J, Liu X, Wu C and Zou J: Long noncoding RNA (IncRNA) HOTAIR affects tumorigenesis and metastasis of non-small cell lung cancer by up-regulating miR-613. Oncol Res 26: 725-734, 2018

101. Lin PC, Huang HD, Chang CC, Chang YS, Yen JC, Lee CC, Chang WH, Liu TC and Chang JG: Long noncoding RNA TUG1 is downregulated in non-small cell lung cancer and can regulate CELF1 on binding to PRC2. BMC Cancer 16: 583, 2016.

102.Zhang EB, Yin DD, Sun M, Kong R, Liu XH, You LH Han L, Xia R, Wang KM, Yang JS, et al: P53-regulated long non-coding RNA TUG1 affects cell proliferation in human non-small cell lung cancer, partly through epigenetically regulating HOXB7 expression. Cell Death Dis 5: e1243, 2014

103. Liu H, Zhou G, Fu X, Cui H, Pu G, Xiao Y, Sun W, Dong X, Zhang L, Cao $\mathrm{S}$, et al: Long noncoding RNA TUG1 is a diagnostic factor in lung adenocarcinoma and suppresses apoptosis via epigenetic silencing of BAX. Oncotarget 8: 101899-101910, 2017.

104. Zhao Z, Wang J, Wang S, Chang H, Zhang T and Qu J: LncRNA CCAT2 promotes tumorigenesis by over-expressed Pokemon in non-small cell lung cancer. Biomed Pharmacother 87: 692-697, 2017.

105. Qiu M, Xu Y, Yang X, Wang J, Hu J, Xu L and Yin R: CCAT2 is a lung adenocarcinoma-specific long non-coding RNA and promotes invasion of non-small cell lung cancer. Tumour Biol 35: 5375-5380, 2014

106. Wang C, Han C, Zhang Y and Liu F: LncRNA PVT1 regulate expression of HIF1 $\alpha$ via functioning as ceRNA for miR199a5p in nonsmall cell lung cancer under hypoxia. Mol Med Rep 17: 1105-1110, 2018.

107. Li H, Chen S, Liu J, Guo X, Xiang X, Dong T, Ran P, Li Q, Zhu B, Zhang X, et al: Long non-coding RNA PVT1-5 promotes cell proliferation by regulating miR-126/SLC7A5 axis in lung cancer. Biochem Biophys Res Commun 495: 2350-2355, 2018.

108. Guo D, Wang Y, Ren K and Han X: Knockdown of LncRNA PVT1 inhibits tumorigenesis in non-small-cell lung cancer by regulating miR-497 expression. Exp Cell Res 362: 172-179, 2018.
109. Wu D, Li Y, Zhang H and Hu X: Knockdown of lncrna PVT1 enhances radiosensitivity in non-small cell lung cancer by sponging Mir-195. Cell Physiol Biochem 42: 2453-2466, 2017.

110. Smolle MA, Bauernhofer T, Pummer K, Calin GA and Pichler M: Current insights into long non-coding RNAs (lncRNAs) in prostate cancer. Int J Mol Sci 18: E473, 2017.

111. Yu X, Zheng H, Chan MT and Wu WK: HULC: An oncogenic long non-coding RNA in human cancer. J Cell Mol Med 21: 410-417, 2017

112. Gutschner T, Hämmerle $M$ and Diederichs S: MALAT1-a paradigm for long noncoding RNA function in cancer. J Mol Med 91: 791-801, 2013.

113. Huarte M: The emerging role of lncRNAs in cancer. Nat Med 21: 1253-1261, 2015.

114. McCleland ML, Mesh K, Lorenzana E, Chopra VS, Segal E, Watanabe C, Haley B, Mayba O, Yaylaoglu M, Gnad F, et al: CCAT1 is an enhancer-templated RNA that predicts BET sensitivity in colorectal cancer. J Clin Invest 126: 639-652, 2016.

115. Zhou Y, Zhang X and Klibanski A: $M E G 3$ noncoding RNA: A tumor suppressor. J Mol Endocrinol 48: R45-R53, 2012.

116. Yap TA, Omlin A and de Bono JS: Development of therapeutic combinations targeting major cancer signaling pathways. J Clin Oncol 31: 1592-1605, 2013

117. Liu XH, Sun M, Nie FQ, Ge YB, Zhang EB, Yin DD, Kong R, Xia R, Lu KH, Li JH, et al: Lnc RNA HOTAIR functions as a competing endogenous RNA to regulate HER2 expression by sponging miR-331-3p in gastric cancer. Mol Cancer 13: 92, 2014.

118. Zhang SR, Yang JK, Xie JK and Zhao LC: Long noncoding RNA HOTTIP contributes to the progression of prostate cancer by regulating HOXA13. Cell Mol Biology 62: 84-88, 2016.

119. Sørensen KP, Thomassen M, Tan Q, Bak M, Cold S, Burton M Larsen MJ and Kruse TA: Long non-coding RNA HOTAIR is an independent prognostic marker of metastasis in estrogen receptor-positive primary breast cancer. Breast Cancer Res Treat 142: 529-536, 2013.

120. Wu ZH, Wang XL, Tang HM, Jiang T, Chen J, Lu S, Qiu GQ, Peng ZH and Yan DW: Long non-coding RNA HOTAIR is a powerful predictor of metastasis and poor prognosis and is associated with epithelial-mesenchymal transition Rep 32: 395-402, 2014.

121. Svoboda M, Slyskova J, Schneiderova M, Makovicky P, Bielik L, Levy M, Lipska L, Hemmelova B, Kala Z, Protivankova M, et al: HOTAIR long non-coding RNA is a negative prognostic factor not only in primary tumors, but also in the blood of colorectal cancer patients. Carcinogenesis 35: 1510-1515, 2014.

122. Kogo R, Shimamura T, Mimori K, Kawahara K, Imoto S, Sudo T, Tanaka F, Shibata K, Suzuki A, Komune S, et al: Long noncoding RNA HOTAIR regulates polycomb-dependent chromatin modification and is associated with poor prognosis in colorectal cancers. Cancer Res 71: 6320-6326, 2011

123. Huang L, Liao LM, Liu AW, Wu JB, Cheng XL, Lin JX and Zheng M: Overexpression of long noncoding RNA HOTAIR predicts a poor prognosis in patients with cervical cancer. Arch Gynecol Obstet 290: 717-723, 2014.

124. Ji F, Wuerkenbieke D, He Y and Ding Y: Long noncoding RNA HOTAIR: An oncogene in human cervical cancer interacting with MicroRNA-17-5p. Oncol Res 2017. Doi: 10.3727/09650401 7X15002869385155.

125. Wu X, Cao X and Chen F: LncRNA-HOTAIR activates tumor cell proliferation and migration by suppressing MiR-326 in cervical cancer. Oncol Res 2017. Doi: 10.3727/096504017X15 037515496840.

126. Endo H, Shiroki T, Nakagawa T, Yokoyama M, Tamai K, Yamanami H, Fujiya T, Sato I, Yamaguchi K, Tanaka N, et al: Enhanced expression of long non-coding RNA HOTAIR is associated with the development of gastric cancer. PLoS One 8: e77070, 2013.

127. Hajjari M, Behmanesh M, Sadeghizadeh M and Zeinoddini M: Up-regulation of HOTAIR long non-coding RNA in human gastric adenocarcinoma tissues. Med Oncol 30: 670, 2013.

128. Chen WM, Chen WD, Jiang XM, Jia XF, Wang HM, Zhang QJ, Shu YQ and Zhao HB: HOX transcript antisense intergenic RNA represses E-cadherin expression by binding to EZH2 in gastric cancer. World J Gastroenterol 23: 6100-6110, 2017.

129. Yan J, Dang Y, Liu S, Zhang Y and Zhang G: LncRNA HOTAIR promotes cisplatin resistance in gastric cancer by targeting miR-126 to activate the PI3K/AKT/MRP1 genes. Tumour Biol: Nov 30, 2016 (Epub ahead of print). 
130. Lin YH, Wu MH, Huang YH, Yeh CT, Cheng ML, Chi HC Tsai CY, Chung IH, Chen CY and Lin KH: Taurine upregulated gene 1 functions as a master regulator to coordinate glycolysis and metastasis in hepatocellular carcinoma. Hepatology 67: 188-203, 2018.

131. Zhao L, Sun H, Kong H, Chen Z, Chen B and Zhou M: The Incrna-TUG1/EZH2 axis promotes pancreatic cancer cel proliferation, migration and EMT phenotype formation through sponging mir-382. Cell Physiol Biochem 42: 2145-2158, 2017.

132. Liu Q, Liu H, Cheng H, Li Y, Li X and Zhu C: Downregulation of long noncoding RNA TUG1 inhibits proliferation and induces apoptosis through the TUG1/miR-142/ZEB2 axis in bladder cancer cells. Onco Targets Ther 10: 2461-2471, 2017.

133. Yu Y, Nangia-Makker P, Farhana L and Majumdar AP: A novel mechanism of lncRNA and miRNA interaction: CCAT2 regulates miR-145 expression by suppressing its maturation process in colon cancer cells. Mol Cancer 16: 155, 2017.
134. Hua F, Li CH, Chen XG and Liu XP: Long noncoding RNA CCAT2 Knockdown suppresses tumorous progression by sponging miR-424 in epithelial ovarian cancer. Oncol Res 26: 241-247, 2018.

135. Li T, Meng XL and Yang WQ: Long noncoding RNA PVT1 acts as a 'Sponge' to inhibit microRNA-152 in gastric cancer cells. Dig Dis Sci 62: 3021-3028, 2017.

136. Huang T, Liu HW, Chen JQ, Wang SH, Hao LQ, Liu M and Wang B: The long noncoding RNA PVT1 functions as a competing endogenous RNA by sponging miR-186 in gastric cancer. Biomed Pharmacother 88: 302-308, 2017.

137. Zhao L, Kong H, Sun H, Chen Z, Chen B and Zhou M: LncRNA-PVT1 promotes pancreatic cancer cells proliferation and migration through acting as a molecular sponge to regulate miR-448. J Cell Physiol 233: 4044-4055, 2018. 